\title{
NULLUM CRIMEN SINE LEGE
}

\section{R. POPOVICIU}

\section{LAURA-ROXANA POPOVICIU}

Faculty of Juridical and Administration Sciences, the Law Department

Agora University of Oradea, Romania

Correspondence: Laura-Roxana Popoviciu, Agora University, 8 PiaţaTineretului St., Oradea, Romania

E-mail: lpopoviciu@yahoo.com

ABSTRACT: This article discusses the issue of one of the most important Latin expressions that establish at the level of general principle that no crime exists outside the law.

The purpose of the criminal law being the defense against the offenses of the right order, ensuring this order implies a strict respect of the principle of legality.

Part of the principle of legality, the legality of incrimination, was formulated among the first, by the Beccaria in Dei delitti e delle pene and proclaimed also in the Declaration of Human and Citizen Rights (1789).

Subsequently, the principle of legality of incrimination was passed in most criminal codes and even in some constitutions.

The Romanian penal code emphasizes that the incriminations can only take place by law, not by other normative acts.

In our law, crime is the sole basis of criminal liability.

The second part of the principle of legality stipulates the legality of the punishments, so that, the crime being the only theme of the criminal liability, at the time of the commission the sanction must also intervene. Only when the sanction intervenes, it must be taken into account in particular that by sanctioning the offenders and the way in which the punishments are enforced some fundamental rights of the person are restricted, such as: freedom of movement, enshrined in all democratic constitutions, free development of the personality of the man and of his participation in the social and economic life, in the family life, the interruption of the professional activity and not lastly the affectation of his dignity. Therefore legality is a fundamental principle of criminal law: the criminalization can only take place through a law, and the sanction only if it is provided by law.

KEYWORDS: crime, Criminal Code, fundamental principle, incrimination, law

\section{INTRODUCTION}

From the summary of the classifications and statements given by the criminal law theorists regarding the fundamental principles of criminal law, it is determined that the principle of legality is of the utmost importance because under this sign stands the entire edifice of modern criminal law.

The principle of legality is unanimously considered to be one of the fundamental principles of the European Union, included in the law of all European states and in the international treaties in criminal matters, which explains the very small number of the judgments of the Court regarding this aspect. 


\section{NULLUM CRIMEN SINE LEGE}

The principle of legality is a unanimous principle also admitted in the criminal doctrine of Romania, which expresses the rule that the entire activity in the field of criminal law is carried out on the basis of the law and in accordance with it ${ }^{1}$.

The principle of legality has an absolute character.

\subsection{LEGALITY}

From the fundamental principles provided by criminal law, some have been proclaimed since ancient times.

The great philosophers of antiquity, Socrates, Plato and Aristotle, who influenced to the greatest extent Western legal thinking, made clear references to the problems of law and force, proclaiming, without any doubt, the rule of law.

Also, Beccaria states: „only the law can determine the penalties corresponding to the crimes and this authority can be held only by the legislator, who represents the whole society brought together by a social contract. Every citizen must know in which situation he is guilty and in which situation he is innocent".

The criminal law, as a form of expression of the law, represents a set of norms that stipulate what facts constitute offenses, the sanctions that can be applied to the offenders and the measures that can be taken in case of committing these facts.

Because the legal norms establish a well-determined conduct whose non-compliance attracts sanctions from the courts, the necessity of their elaboration, adoption and promulgation through a special procedure at the level of the legislative bodies was imposed ${ }^{2}$.

The legislator, in the rule of incrimination describes the crime and at the same time provides a sanction for that fact, drawing a line between the criminal and extra-criminal illegal acts.

In this way, it separates the field of the facts that constitute offenses from those that are subject to the extra-penal norms or which are allowed by law.

These limits of demarcation can not be exceeded in any way, neither by the way of extending the incrimination on other facts not included in the description from the criminal law, nor by the way of the interpretation of the criminal law ${ }^{3}$.

Only the criminal law can determine the facts that constitute crimes and attract the criminal liability of a person as well as the sanctions that apply to those who commit crimes.

Incrimination and punishment can only be the work of the legislator.

What provide to the crime the criminal offense is its provision in the norm of incrimination or, in other words, the criminal nature of the crime depends on the will of the legislator and not on the objective reality ${ }^{4}$.

Criminal law means any provision that regulates social defense relations.

The term „criminal law” is used in its usual legal sense, as a normative act containing provisions of criminal law.

\footnotetext{
${ }^{1}$ C-tin. Mitrache, C. Mitrache, Romanian criminal law. General part, Bucharest, Universul Juridic Publishing House, 2006, pg. 44

${ }^{2}$ F. Ivan, Criminal law. General part, Romanian University Press Publishing House, Timişoara, 2001, pg. 21

3 V. Dongoroz, S. Kahane, I. Oncea, I. Fodor. N. Iliescu, C. Bulai, R. Stănoiu, Theoretical explanations of the Romanian Criminal Code, Vol. I, Second Edition, Romanian Academy Publishing House, All Beck Publishing House, Bucharest, 2003, pg. 36

${ }^{4}$ F. Ivan, same refference, pg. 21
} 


\section{Laura-Roxana Popoviciu}

By criminal law we can say that we understand all the provisions that refer to the conditions of incrimination and punishment and to the conditions for taking criminal responsibility contained in:

- the penal code, as a general basic law in criminal matters, where the majority of the norms of general and special criminal character are included;

- special criminal laws;

- criminal provisions from non-penal laws.

The Criminal Code has two parts:

- The general part (corresponding to the norms of the General Part of the Criminal Code) which contains rules regarding the criminal law and its application, crime and offender, criminal sanctions and criminal liability.

- The special part (corresponding to the norms of the special part of the Criminal Code and of special laws) which contains rules that establish the concrete content of each particular offense as well as the sanctions that apply to these crimes.

Special criminal laws are those laws which provide for certain offenses or which regulate the criminal liability of persons who have a certain quality, or which regulate certain areas of social life: the law on combating trafficking and illicit drug use, the Law on the prevention and sanctioning of acts of corruption.

\subsection{THE LEGALITY OF THE INCRIMINATION}

According to art. 2 of the Criminal Code, "the law provides for the facts that constitute offenses, the penalties that are applied and the measures that can be taken in case of committing these facts".

The offense is a fact prohibited by law which is sanctioned by the legislator by drawing to criminal liability.

The offense consists in committing the act of conduct that is prohibited by the norm of incrimination.

The concrete fact must be related to an incrimination rule, to a legal model in order to be assigned the crime character.

It was argued in the doctrine $e^{5}$ that, in a certain way, the norm of incrimination creates, from a legal point of view, the crime; it confers this quality on the concrete crime, only by reference to the norm and insofar as the features of the concrete crime coincide, they overlap those of the legal model ${ }^{6}$, a fact cloaks the legal offense and can be subject to criminal sanction.

It has been stated ${ }^{7}$ that the law is an act of legal creation.

A fact is not a crime unless the norm incriminates and sanctions it.

"With the help of the incrimination norm, the legislator achieves its objectives of criminal policy; the criminal norm includes the requirements that the company formulates regarding the behavior of the recipients of the norm. Any change in the criminal policy of the state takes place through changes brought to the incrimination norm (disincrimination, incrimination of new facts, modification of the content of some incriminations, etc.) ${ }^{" 8}$.

\footnotetext{
${ }^{5}$ G. Antoniu, Reflections on the structure of the incriminating norm, in R.D.P. no. 3/1998, pg, 9

6 V. Dongoroz V., Criminal law, Bucharest, Tempus Society Publishing House \& Romanian Association of Criminal Sciences, 2000, pg. 211

${ }^{7}$ G. Antoniu, same refference, pg. 9

${ }^{8}$ Idem
} 


\section{NULLUM CRIMEN SINE LEGE}

\subsection{THE CRIME INCRIMINATED}

The legislator at the time of elaboration the criminal law will first of all, have to describe the fact that he understand to incriminate.

He must show the dangerous action, that is to say the active intervention of the individual, that is to say a dangerous activity that is prohibited by law, or the inaction characterized by the passive attitude of the individual, manifested when the law requires him to carry out a certain activity and he abstains to fulfill it.

The action can consist in a single act (for example a hit), in several acts, identical (several repeated hits in the same circumstance) or in several different acts (for example, a hit and a shot).

The means of accomplishing the illicit action are very varied, in some cases using the energy of the agent; in others, the action takes place by means of instruments, forces, inanimate or inanimate objects.

„Inaction is the opposite of the action, so the attitude, the negative behavior: the perpetrator remains in passivity, does not act as he was obliged. In order for the inaction to be criminally relevant, there must therefore be a legal, conventional or natural duty for the perpetrator to act in a certain way"

Committing the act or inaction incriminated must produce a dangerous consequence.

The dangerous consequence is that negative modification of the surrounding reality that the committed act has produced or is likely to produce and which finds its expression in the danger, injury or threat of the social values defended by the criminal law ${ }^{10}$.

The material act must be finalized by a result, an effect, a consequence, which is practically the external form of manifestation of the criminal action or inaction, revealing its purpose.

In social life, any cause necessarily produces an immediate, direct consequence.

Thus, between the criminal action or inaction and the socially dangerous consequence there must be a causal link, a link from cause to effect.

Although the law does not expressly provide for the causal link between the conditions of existence of the crime, this link is a constituent element of the content of any crime.

In addition to the illegal action or inaction, the socially dangerous follow-up and the causal relationship between them, in the commission of an offense may also be provided circumstances related to the place, time, manner and means used in committing it.

Although, in any crime, the dangerous action or inaction as well as the psychic attitude with which they were committed appear, they cannot be viewed separately from the person of the perpetrator and from the social values harmed or endangered.

Seen from a logical point of view, an offense is made up of certain elements identified and defined in the criminal law.

All the elements of the crime form the content of the crime.

In the Criminal Code in force, the notion of crime in general has received, within a legal norm a precise formulation: it is the act provided by the criminal law committed with guilt, unjustified and imputable to the one who committed it.

\footnotetext{
${ }^{9}$ V. Dongoroz, same refference, 2003, pg. 108

10 A. Boroi, Criminal law. General part. Under the New Criminal Code, C. H. Beck Publishing House, Bucharest, 2010, pg. 166
} 


\section{Laura-Roxana Popoviciu}

The Declaration of Human and Citizen Rights of August 26, 1789 proclaims that „people are born and remain free and equal in rights. Social distinctions can only be founded on the common utility" (art. 1).

The law „must be the same for all, whether it defends or punishes,, (art. 6) and „no man can be accused, arrested or detained except in the cases determined by law, according to the procedure provided by it, (art. 7).

Universal Declaration of Human Rights „no one will be convicted for actions or omissions that did not constitute when a criminal act was committed in accordance with international or national law,, International Covenant on Civil and Political Rights adopted in 1966 „Nobody will not be convicted for actions or omissions that did not constitute a criminal act, according to national or international law, at the time they were committed,", and the Convention for the Protection of Human Rights and Fundamental Freedoms outlines the international framework in which two fundamental principles are found. of criminal law: the principle of legality of incriminations and punishments and the principle of equality before the law.

Taken from the national constitutions of the signatory states, these principles receive constitutional value.

\subsection{THE PRINCIPLE OF LEGALITY}

The principle of legality is expressly provided in the Romanian Criminal Code:

„Art. 1. - (1) The criminal law provides the facts that constitute offenses.

(2) No person shall be penalized for a crime that was not provided for by the criminal law at the time when it was committed".

This principle is the basis of criminal liability.

Only when a person knows what is allowed by law and what is forbidden can he act freely, he can adopt the attitude he wants towards the law freely.

From this principle some authors ${ }^{11}$ see four consequences:

„-- reservation of the regulation in criminal matters exclusively to the criminal law;

- express and precise determination of criminal acts;

- non-retroactivity of criminal law and

- prohibition of analogy in criminal matters".

Other authors ${ }^{12}$ refer to this principle as a guarantee for respect for human rights.

According to theprinciple of legality, the activities carried out by forensic experts involved in criminal investigations may only be ordered, performed and exploited in compliance with the provisions of the Criminal Procedure Code. However, the tactical methods applied and the technical-scientific means used during their deployment must also be based on the rules of forensic science set out in best practice guides, which are not detailed in the legislation but are applicable in the matter.

\section{CONCLUSIONS}

The principle of the legality of the incrimination expressed by the Latin dictum nullum crimen sine lege imposes the necessity for the crime to be incriminated in a legal text.

\footnotetext{
${ }^{11}$ V. Pasca, Course on criminal law. General part with the amendments of the new Criminal Code, Bucharest, Universul Juridic Publishing Housepg. 32

${ }^{12}$ E. A. Iancu, The Contribution of Forensic Science to Establishing the Truth in Criminal Proceedings, în Athens Journal of Law -Volume 5, Issue 4, pg. 459, DOI: 10.30958/ajl_v5i4
} 


\section{NULLUM CRIMEN SINE LEGE}

The legality of the incrimination is a strong guarantee of respecting the rights and freedoms of the citizen who cannot be held responsible for behavior that is not provided for in the law as illegal.

\section{BIBLIOGRAPHY:}

G. Antoniu, Reflections on the structure of the incriminating norm, in R.D.P. no. 3/1998;

A. Boroi, Criminal law. General part. Under the New Criminal Code, C. H. Beck Publishing House, Bucharest, 2010;

V. Dongoroz, S. Kahane, I. Oncea, I. Fodor. N. Iliescu, C. Bulai, R. Stănoiu, Theoretical explanations of the Romanian Criminal Code, Vol. I, Second Edition, Romanian Academy Publishing House, All Beck Publishing House, Bucharest, 2003;

V. Dongoroz V., Criminal law, Bucharest, Tempus Society Publishing House \& Romanian Association of Criminal Sciences, 2000;

E. A. Iancu, The Contribution of Forensic Science to Establishing the Truth in Criminal Proceedings, în Athens Journal of Law -Volume 5, Issue 4;

F. Ivan, Criminal law. General part, Romanian University Press Publishing House, Timişoara, 2001;

C-tin. Mitrache, C. Mitrache, Romanian criminal law. General part, Bucharest, Universul Juridic Publishing House, 2006;

V. Pasca, Course on criminal law. General part with the amendments of the new Criminal Code, Bucharest, Universul Juridic Publishing House. 